\title{
PENGEMBANAGAN APLIKASI PRESENSI PEGAWAI BERBASIS FINGERPRINT
}

\author{
Mohammad Syahidul Haq \\ Jurusan Manajemen Pendidikan, Fakultas Ilmu Pendidikan \\ Universitas Negeri Surabaya \\ e-mail: mohammadhaq@unesa.ac.id
}

\begin{abstract}
Abstrak
Tujuan pengembangan ini adalah untuk mendeskripsikan desain sistem aplikasi presensi pegawai berbasis fingerprint di sekolah, memberikan kemudahan dalam pelakukan presensi pegawai di sekolah agar terekam dengan baik. Rancangan penelitian yang digunakan dalam penelitian ini adalah menggunakan rancangan penelitian pengembangan model prosedural. Produk yang dihasilkan dalam penelitian ini adalah aplikasi presensi pegawai berbasis fingerprint. Dalam penelitian ini dimaksudkan mengembangkan produk presensi pegawai yang sebelumnya menggunakan model manual dikembangkan berbasis fingerprint selanjutanya dilakukan validasi oleh ahli dalam rangka memperoleh kelayakan toori, kelayakan praktis, dan kelayakan produk.
\end{abstract}

Kata Kunci: Pengembangan, Aplikasi, Fingerprint.

\section{PENDAHULUAN}

Perkembangan ilmu pengetahuan dan teknologi di era globalisasi saat ini telah berkembang pesat. Perkembangan ilmu pengetahuan dan teknologi tersebut terjadi di berbagai bidang, salah satunya bidang pendidikan, yakni dengan munculnya peralatan-peralatan teknologi canggih yang dapat meningkatkan motivasi dan produktivitas untuk menghadapi persaingan di era globalisasi. Peningkatan motivasi dan produktivitas merupakan tantangan baru bagi dunia pendidikan dalam mengembangkan sumber daya manusia.

Pengembangan sumber daya manusia memerlukan sikap disiplin yang bertujuan untuk mendapatkan hasil yang maksimal dalam menghadapi kemajuan dan tantangan baru dalam pekerjaan. Salah satu bentuk upaya yang sudah dilakukan oleh pemerintah untuk memenuhi tuntutan tersebut, yaitu dengan diprogramkan Gerakan Disiplin Nasional (GDN) dari menteri Negara Koordinator Bidang Politik dan Keamanan Republik Indonesia tanggal 5 Mei 1996 No. B/36/Menko/Polkam/1995 (Dalam Huda, 2010:107) yang mengemukakan "Sekolah sebagai lembaga pendidikan dan pengajaran formal merupakan sumber disiplin dan tempat berdisiplin untuk mencapai ilmu pengetahuan”. Untuk itu, disiplin tidak hanya dilakukan di lembaga nonpendidikan namun juga dilakukan di lembaga pendidikan.

Disiplin dapat diartikan sebagai ketaatan pada peraturan yang berlaku di lingkungan lembaga. Disiplin merupakan aspek dalam membentuk peserta didik, pendidik dan tenaga kependidikan dalam upaya mengembangkan pemahaman diri, berperilaku baik dan berprestasi. Dengan menumbuhkan sifat disiplin di sekolah kegiatan belajar mengajar dapat berjalan dengan efektif, efisien, dan bertanggung jawab. Upaya yang dilakukan bertujuan untuk membina disiplin di lingkungan lembaga pendidikan dan dapat dijadikan dasar untuk berperilaku disiplin yang baik. Hal ini dikarenakan pembinaan disiplin dapat mempengaruhi perilaku pendidik dan tenaga kependidikan maupun warga sekolah lainnya agar menjadi lebih baik.

Tujuan sekolah maupun tujuan pendidikan secara keseluruhan diupayakan memberi dukungan bagi terciptanya perilaku yang tidak menyimpang dan mendorong peserta didik, pendidik dan tenaga kependidikan berperilaku yang baik dan benar. Untuk itu, diperlukan peraturan atau tata-tertib sekolah yang mengatur peserta didik, pendidik, dan tenaga kependidikan dalam segala tindakan di sekolah. Perilaku disiplin yang dilakukan dapat dipengaruhi oleh beberapa faktor. Hal ini diungkapkan oleh Huda (2010:109) “..., disiplin dapat terbentuk karena ada pengaruh eksternal dan internal. Pengaruh eksternal dapat berupa peraturan-peraturan yang harus dipatuhi, sedangkan pengaruh internal dapat berupa dorongan dari dalam diri individu untuk berlaku tertib dan disiplin". Dengan demikian, peraturan atau tatatertib sekolah merupakan perwujudan dari pelaksanaan kedisiplinan di sekolah. 
Lembaga pendidikan maupun nonpendidikan dalam menerapkan disiplin hadir tepat waktu menggunakan berbagai macam sistem untuk mengawasi seluruh warga sekolahnya. Umumnya, sistem kehadiran yang dijalankan di lembaga pendidikan maupun lembaga non-pendidikan masih menggunakan sistem manual, yakni presensi menggunakan tanda tangan maupun pengecekan secara individu, sehingga dapat terjadi pelanggaran dalam presensi pendidik, dan tenaga kependidikan. Pelanggaran yang dimaksud, yaitu penitipan presensi dan manipulasi waktu kehadiran di sekolah. Seiring dengan perkembangan IPTEK, terdapat sebuah teknologi yang dapat mengurangi maupun mengatasi permasalahan tentang disiplin hadir tepat waktu di lingkungan lembaga. Umumnya, teknologi tersebut digunakan di lembaga non-pendidikan. Namun, lembaga pendidikan juga harus dapat mengikuti perkembangan dalam penggunaan teknologi.

Kedisiplinan adalah "kesadaran dan kesediaan seseorang menaati semua peraturan sekolah dan norma-norma sosial yang berlaku" (Hasibuan, 2007:193). Untuk itu, kedisiplinan sekolah merupakan kesadaran dan kesediaan seluruh warga sekolah dalam mentaati semua peraturan atau tata-tertib yang berlaku di sekolah. Salah satu peraturan sekolah yang juga menjadi topik penelitian yaitu kehadiran di sekolah oleh pendidik dan tenaga kependidikan. Kehadiran yang dimaksud yaitu ketepatan waktu hadir ke sekolah, baik pendidik maupun tenaga kependidikan dan segala perilakunya saat berada di lingkungan sekolah.

Kehadiran pendidik dan tenaga kependidikan terlambat hadir ataupun tidak hadir, maka proses pembelajaran di kelas tidak dapat berjalan lancar dan kinerja yang berhubungan dengan sekolah akan terhambat. Dengan demikian, disiplin hadir tepat waktu di lembaga pendidikan maupun lembaga non-pendidikan sangat penting untuk diterapkan.

Banyak sekolah di wilayah kota malang yang menerapkan aplikasi fingerprint untuk seluruh pendidik, dan tenaga kependidikan. Hal ini dilakukan untuk menghindari terjadinya kecurangan waktu yang dilakukan oleh pendidik, dan tenaga kependidikan jika terlambat hadir di sekolah. Untuk itu lembaga pendidikan (sekolah) menyediakan sebuah alat fingerprint, yaitu peralatan presensi yang merekam sidik jari pendidik, dan tenaga kependidikan saat jam datang dan jam pulang, sehingga pendidik, dan tenaga kependidikan tidak bisa lagi menitip presensi kepada temannya maupun memanipulasi waktu saat terlambat hadir, karena peralatan ini hanya merekam sidik jari yang bersangkutan, selain itu peralatan ini bekerja secara otomatis dan dapat dipantau dari komputer yang terhubung dengan peralatan tersebut. Fingerprint ini juga memudahkan bagi administrator untuk merekap presensi pendidik, dan tenaga kependidikan secara sistematis. Untuk mengatasi masalah-masalah yang disebutkan di atas dapat dilakukan dengan cara komputerisasi dengan membangun sebuah sistem pendukung. Faktor untuk menentukan keberhasilan suatu penerapan sistem presensi dapat diuraikan menjadi 3 Faktor (Fajrin, 2012:15), yaitu (a) kebenaran data, (b) waktu proses, dan (c) biaya pengadaan. Perbandingan kebenaran data, dari tingkat kedisiplinan bisa dibedakan mana yang datang terlambat atau tidak. Perbandingan waktu proses, dengan menggunakan mesin fingerprint waktu yang dibutuhkan dalam proses presensi akan jauh lebih singkat, karena untuk satu kali rekam sidik jari hanya berdurasi \pm 5 detik. Sedangkan, perbandingan biaya pengadaan, pencatatan kehadiran menggunakan sidik jari membutuhkan biaya yang lebih besar dibandingkan dengan pencatatan kehadiran secara manual.

\section{METODE}

Rancangan penelitian yang digunakan dalam penelitian ini adalah menggunakan rancangan penelitian pengembangan model prosedural. Model prosedural adalah model yang bersifat deskriptif, yaitu menggunakan langkah-langkah yang harus diikuti untuk menghasilkan produk. Model prosedural yang dipilih mengadaptasi model penelitian dan pengembangan (Research And Development/R \& D) Borg Dan Gall (Dalam Surjono, 2009:148) dan rancangan model prosedural yang dikembangkan oleh Mckenny (Dalam Surjono, 2009:148). Dalam penelitian dan pengembangan pada dasarnya ada dua tujuan utama, yaitu (1) mengembangkan produk dan (2) menguji keefektifan produk. Tujuan pertama sebagai fungsi pengembangan dan tujuan kadua sebagai fungsi validasi (Sukmadinata Dalam Surjono, 2009:148). Dalam penelitian ini dimaksudkan untuk mengembangkan aplikasi presensi pegawai dari semula manual dikembangkan ke menggunakan sistem fingerprint, sekaligus memvalidasi dalam rangka memperoleh 
kelayakan teori, kelayakan praktis maupun kelayakan produk.

Tahap penelitian yang dirancang merupakan modifikasi dari sepuluh langkah penelitian dan pengembangan dari Borg Dan Gall. Dari sepuluh langkah tersebut, kemudian dimodifikasi menjadi 3 langkah penelitian dan pengembangan. Tiga langkah tersebut intinya sama dengan tahapan penelitian yang dilakukan oleh Mckenny (dalam Surjono, 2009:148), yaitu meliputi (1) tahap studi pendahuluan sebagai Needs And Contens Analysis, (2) tahap pengembangan sebagai Design, Development, And Evaluation Stage, dan (3) tahap pengujian efektifitas produk sebagai Semi-Sumative Evaluation.

Adapun model yang akan dikembangkan adalah mengikuti siklus alur sistem. Ada beberapa siklus pengembangan sistem dari para ahli, antara lain Sander (dalam Suryana, 2007:49) mengidentifikasi siklus pengembangan sistem menjadi 5, antara lain " definisi masalah (problem definition), analisis sistem (system analysis), desain sistem (system design), dan implementasi sistem (system implementation)“. Sementara itu Davis (dalam Suryana, 2007:49) menyebutkan terdapat 7 tahapan siklus dalam pengembangan sistem, yaitu "definisi masalah, studi kelayakan, analisis, desain sistem, desain terinci, implementasi, dan perawatan". Sedangkan Scott (dalam Suryana, 2007:49) merincinya sebagai berikut "studi pendahuluan, analisis sistem, desain sistem, dan implementasi". Lebih lanjut Scott membagi implementasi menjadi beberapa tahap, yaitu "pelatihan, penyeleksian program, pemrograman, persiapan tempat, instalasi, peralatan, konversi, dan penerimaan".

Dari ketiga ahli di atas, secara garis besar disimpulkan sebagai berikut:

1. Mendefinisikan masalah adalah untuk memahami masalah secara mendalam. Langkah ini harus sesuai dengan apa yang akan di input pada program, perintah-perintah apa yang akan digunakan dan bagaimana bentuk outputnya. Apabila salah asumsi tentang masalah yang ada, maka akan berakibat program yang dibuat tidak sesuai yang dikehendaki.

2. Untuk mendapatkan dan menemukan permasalahan yang akan diteliti ternyata sangatlah perlu untuk melakukan studi pendahuluan. Adapun cara melakukan studi pendahuluan yaitu dengan menemukan tema permasalahan yang akan diteliti melalui survei pustaka guna mendalami teori yang ada.

3. Analisis sistem adalah sebuah teknik pemecahan masalah yang menguraikan sebuah sistem menjadi bagian-bagian komponen dengan tujuan mempelajari seberapa bagus bagian-bagian komponen tersebut bekerja dan berinteraksi untuk meraih tujuan mereka.

4. Desain sistem adalah tahap yang harus dilakukan dalam perancangan suatu aplikasi yang baik. Tahap yang dilakukan sebelum melakukan koding ini bertujuan agar aplikasi yang dibuat dapat dengan maksimal memenuhi kebutuhan pengguna aplikasi tersebut.

5. Siklus yang terakhir adalah implementasi dari hasil analisis sistem, desain sistem. Dalam tahap ini program diimplementasikan dengan cara memberikan penjelasan bagaimana cara membuat program dan hasilnya diterapkan untuk memenuhi kebutuhan. Siklus pengembanga sistem, dapat dilihat gambar 1 berikut ini.

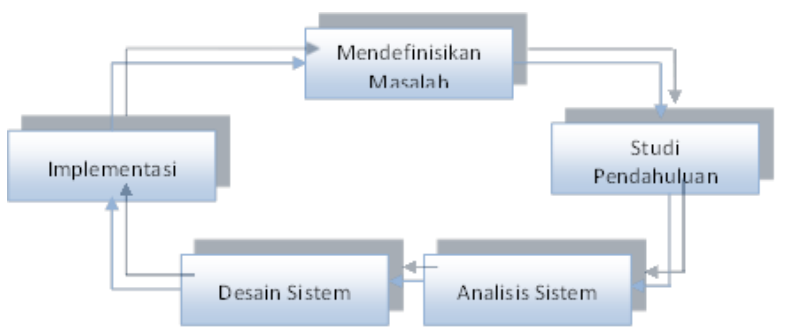

Gambar 1 Siklus Pengembangan Sistem

Model pengembangan yang dilakukan dalam penelitian ini adalah model prosedural yang mengadaptasi pada model r\&d borg dan gall, modifikasi dari sukmanata, dan adaptasi dari McKenny, meliputi tahapan (1) studi pendahuluan, (2) pengembangan, dan (3) pengujian. Oleh karena itu, prosedur pengembangan dalam penelitian ini tinggal mengikuti tahapan tersebut. Prosedur pengembangan yang dilakukan dalam pengembangan ini adalah:

1. Sebelum peneliti mengembangkan sebuah program, terlebih dahulu mendefinisikan permasalahan, yaitu bagaimana mengembangkan aplikasi presensi pegawai berbasis fingerprint di Yayasan Pendidikan Anak Saleh kota Malang 
2. Mendeskripsikan desain aplikasi presensi pegawai berbasis fingerprint yaitu mengidentifikasi informasi apa yang dibutuhkan, kapan, dimana, dalam bentuk apa dan lain sebagainya.

3. Menyusun prototype desain aplikasi presensi pegawai berbasis fingerprint di Yayasan Pendidikan Anak Saleh kota Malang sebagai model yang akan dikembangkan.

4. Melakukan penyusunan (desain) aplikasi presensi pegawai berbasis fingerprint di Yayasan Pendidikan Anak Saleh kota Malang Menggunakan Borland Delphi.

5. Implementasi program, yang terdiri dari beberapa kegiatan, antara lain:

a. Uji coba hasil aplikasi presensi pegawai berbasis fingerprint di Yayasan Pendidikan Anak Saleh Kota Malang oleh beberapa pendidik dan tenaga pedidikan di Yayasan Pendidikan Anak Saleh, untuk memberikan masukan.

b. Perbaikan hasil uji coba.

c. Setelah uji coba dirasa cukup, selanjutnya disusunlah aplikasi presensi pegawai berbasis fingerprint di Yayasan Pendidikan Anak Saleh kota Malang. Kemudian aplikasi di masukkan ke sebuah personal computer agar bisa dimanfaatkan untuk oleh pendidik dan tenaga pedidikan Yayasan Pendidikan Anak Saleh kota Malang.

d. Evaluasi dan follow up program, setelah program di ujicoba selanjutnya mengevaluasi program dengan cara memberikan masukan untuk pengembangan program selanjutnya.

Desain sistem adalah proses penyusunan spesifikasi sistem baru yang diusulkan dari rekomendasi yang dibuat selama analisis sistem. Yang pertama dilakukan yaitu menetapkan ruang lingkup sistem baru. Penyusunan aplikasi presensi pegawai berbasis fingerprint di Yayasan Pendidikan Anak Saleh Kota Malang belum memberikan kemudahan dalam penggunaanya. Dengan permasalahan tersebut rancangan desain dibuat semudah mungkin agar dapat di akses oleh siapa saja. Desain sistem aplikasi presensi pegawai berbasis fingerprint di yayasan pendidikan anak saleh kota malang dapat dilihat pada gambar 2
Uji coba produk dilakukan oleh guru dan staf Yayasan Pendidikan Anak Saleh kota Malang.

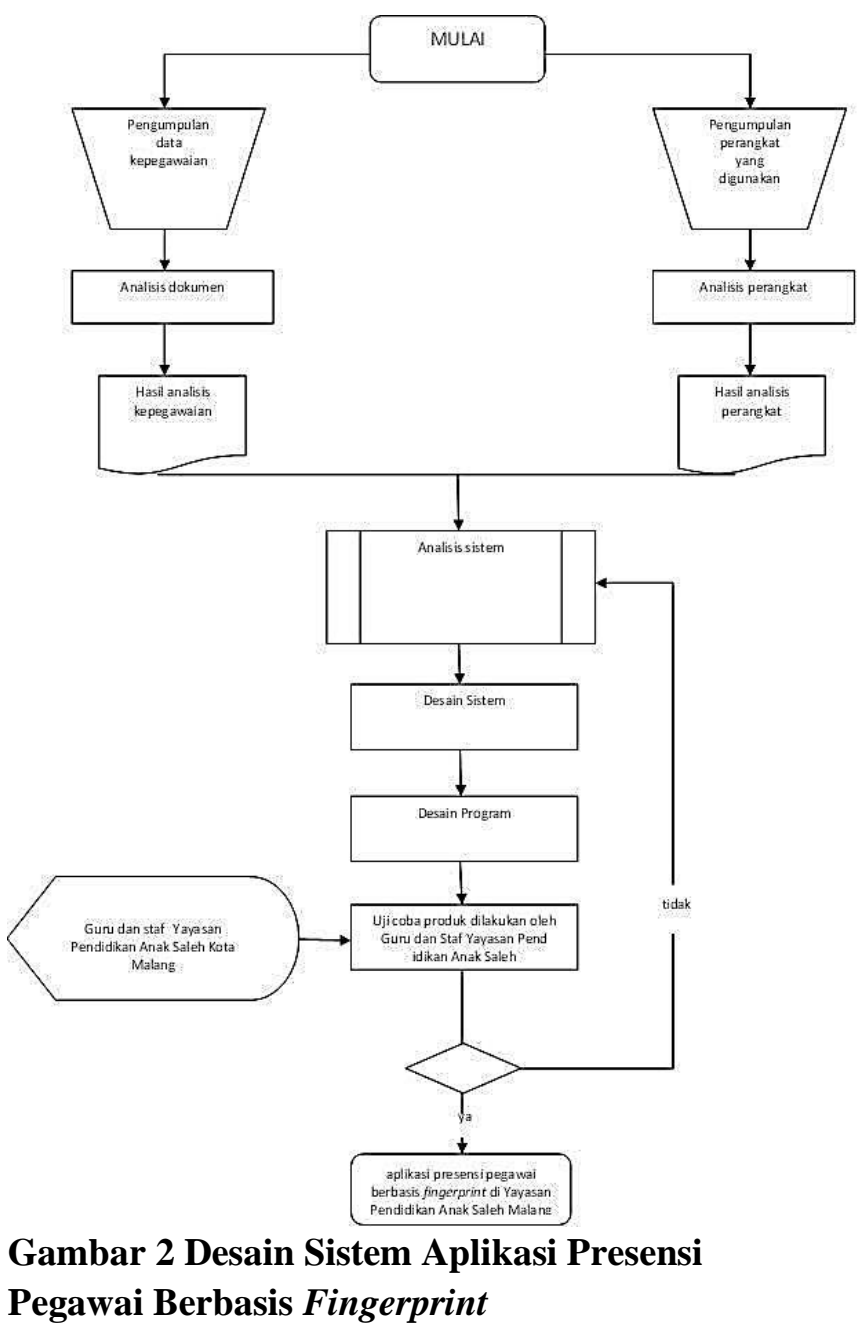

HASIL

Membangun aplikasi presensi kepegawaian berbasis fingerprint sebagai alat bantu dalam pencatatan presensi pegawaian. Aplikasi didesain semudah menggunakan sebuah program pada umumnya. Validasi dilakukan kepada 5 orang ahli media untuk dapat mengetahui kualitas aplikasi presensi pegawai berbasis fingerprint yang sudah dibuat.

Setelah dilakukan validasi ahli media, maka data tersebut perlu dianalisis untuk mendapatkan kesimpulan dari kualitas produk aplikasi yang telah dibuat. Rumus untuk mengolah data ini menggunakan rumus yang telah ditetapkan dan acuan interpretasi data 
disesuaikan berdasarkan kriteria yang telah ditetapkan. Agar lebih mudah dalam membaca hasil analisis ahli media tentang aplikasi presensi pegawai berbasis fingerprint, dapat digambarkan dengan grafik hasil analisis seperti gambar 3

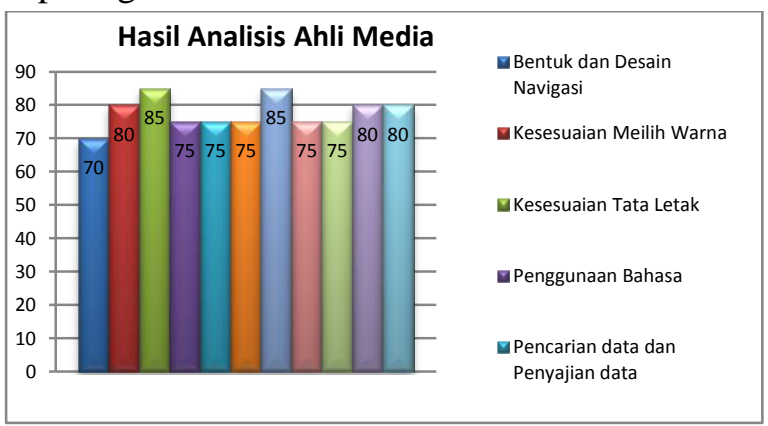

\section{Gambar 3 Hasil Analisis Ahli Media}

Sedangkan angket yang diisi oleh responden dari penguna aplikasi yang terdiri dari tenaga administrasi di Yayasan Pendidikan Anak Saleh kota Malang. Responden dipilih secara acak supaya data yang diperoleh lebih valid dan obyektif. Jumlah responden dipilih sebanyak 10 (responden). Aspek ujicoba meliputi desain, fungsionalitas, nilai pengguna, dan efektifitas pengguna aplikasi. Setelah data tersebut terkumpul selanjutnya dianalisis untuk mendapatkan kesimpulan dari kualitas produk aplikasi presensi pegawai berbasis fingerprint yang telah dibuat. Rumus untuk mengolah data ini menggunakan rumus yang telah ditetapkan dan acuan interpretasi data disesuaikan berdasarkan kriteria yang telah ditetapkan. Berikut ini hasil ujicoba produk dapat dilihat pada gambar 4 berikut ini.

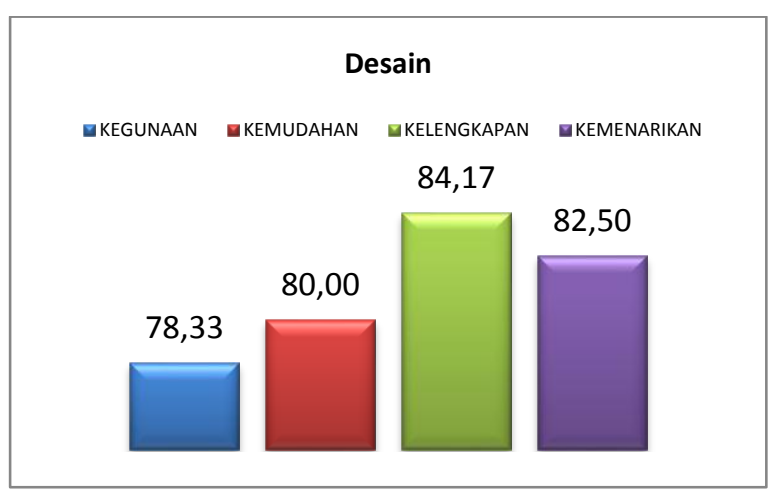

Gambar 4 Persentase Hasil Analisis Uji Lapangan Kategori Desain
Berdasarkan gambar 4 dapat diketahui penilaian kategori desain aplikasi presensi pegawai berbasis fingerprint dari 10 responden yaitu: kegunaan $78,33 \%$, kemudahan $80,00 \%$, kelengkapan $84,17 \%$, dan kemenarikan $82,50 \%$.

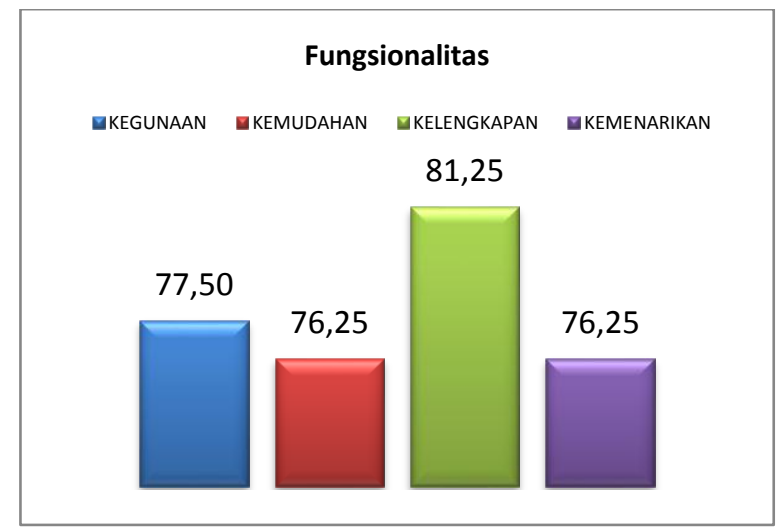

\section{Gambar 5 Persentase Hasil Analisis Uji Lapangan Kategori Fungsionalitas}

Berdasarkan gambar 5 dapat diketahui penilaian kategori fungsionalitas aplikasi presensi pegawai berbasis fingerprint dari 10 responden yaitu: kegunaan $77,50 \%$, kemudahan $76,25 \%$, kelengkapan $84,25 \%$, dan kemenarikan $76,25 \%$.

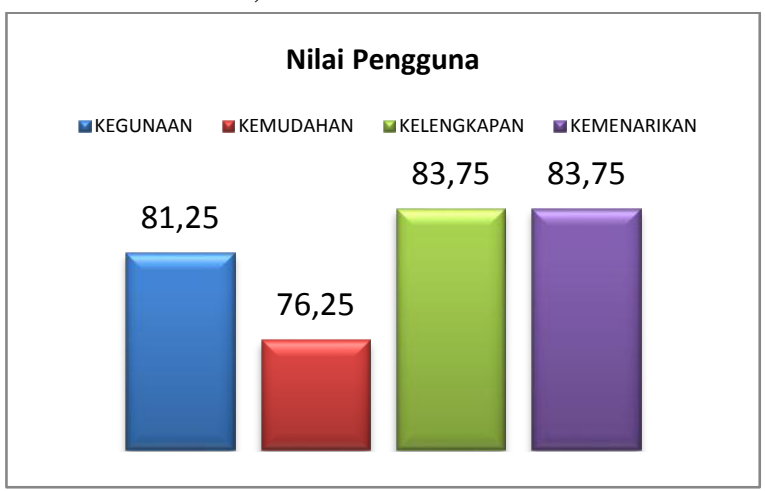

\section{Gambar 6 Persentase Hasil Analisis Uji Lapangan Kategori Nilai Pengguna}

Berdasarkan gambar 6 dapat diketahui penilaian kategori nilai pengguna aplikasi presensi pegawai berbasis fingerprint dari 10 responden yaitu: kegunaan $81,25 \%$, kemudahan $76,25 \%$, kelengkapan $83,75 \%$, dan kemenarikan $83,75 \%$. 


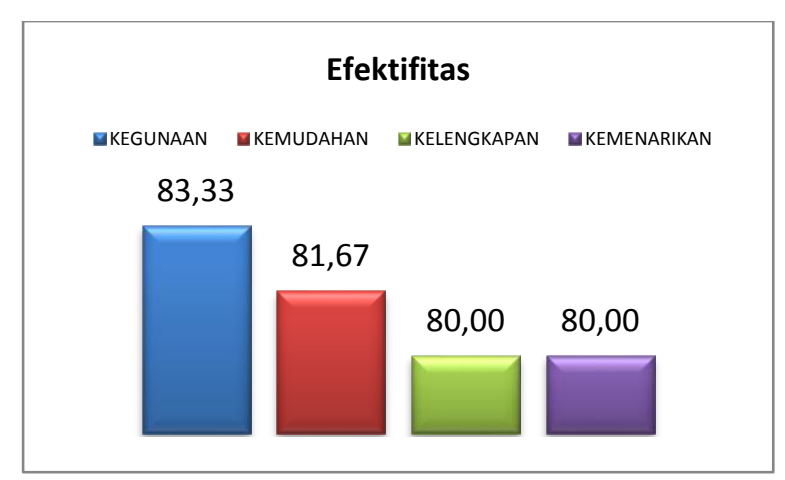

\section{Gambar 7 Persentase Hasil Analisis Uji Lapangan Kategori Efektifitas}

Berdasarkan gambar 7 dapat diketahui penilaian kategori efektifitas aplikasi presensi pegawai berbasis fingerprint dari 10 responden yaitu: kegunaan $83,33 \%$, kemudahan $81,67 \%$, kelengkapan $80,00 \%$, dan kemenarikan $80,00 \%$. Berdasarkan kriteria yang ditetapkan maka dapat diinterpretasikan bahwa aplikasi presensi pegawai berbasis fingerprint yayasan pendidikan anak saleh yang dikembangkan termasuk dalam kriteria cukup valid atau kualifikasi layak digunakan.

Setelah melakukan ujicoba dilakukan revisi produk sesuai masukan dari ahli media dan responden (pengguna) aplikasi presensi pegawai berbasis fingerprint. Beberapa masukan yang diberikan oleh ahli media dan responden diantaranya adalah tampilan utama aplikasi dibuat semenarik mungkin dengan menambahkan beberpa foto kegiatan lembaga pendidikan. Berikut tampilan utama dari aplikasi presensi pegawai berbasis fingerprint yayasan pendidikan anak saleh kota malang seperti Gambar 8.

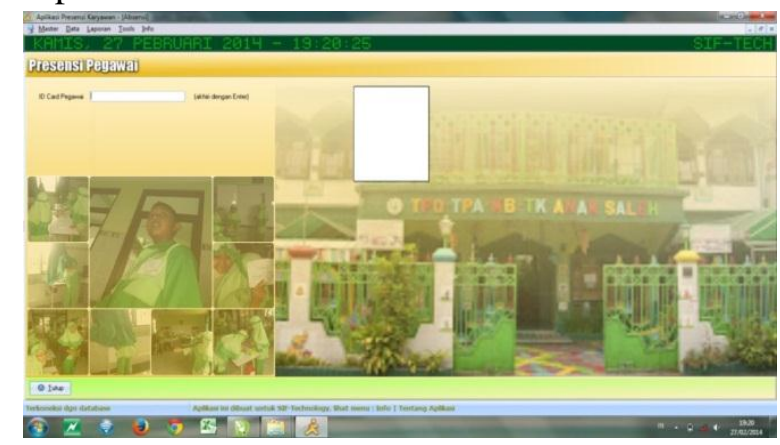

Gambar 8 Tampilan Utama Aplikasi Setelah Revisi

\section{KESIMPULAN DAN SARAN}

Kesimpulan

Pada era teknologi, informasi dan komunikasi telah membawa dampak yang begitu besar terhadap berbagai bidang kehidupan, hasil pengembangan produk ini telah menunjukkan bahwa kehadiran aplikasi ini menjadi alternatif untuk meningkatkan kedisiplinan pegawai.

Hasil pengembangan produk ini memberikan beberapa implikasi, antara lain (1) implikasi terhadap perencanaan dan pengembangan yayasan pendidikan anak saleh kota malang, dalam menghadapi perkembangan maka perlu perancangan mampu bersaing di era globalisasi sehingga dapat merumuskan suatu kebijakan untuk pengembangan dan penyempurnaan teknologi informasi, dan (2) implikasi terhadap pengembangan aplikasi yang merupakan suatu inovasi baru terhadap perkembangan teknologi saat ini yang banyak digunkan oleh masyarakat.

\section{Saran}

Dengan adanya aplikasi presensi pegawai berbasis fingerprint akan mempermudah pembuatan laporan kehadiran pegawai. Setelah aplikasi selesai diharapkan pendidik dan tenaga kependidikan di yayasan pendidikan anak saleh memanfaatkan fasilitas yang ada di aplikasi tersebut. Tujuan dari pengembangan ini adalah presensi pegawai di Yayasan Pendidikan Anak Saleh memberikan kemudahan dalam melakukan presensi dengan menggunakan fingerprint di Yayasan Pendidikan Anak Saleh kota Malang terekam dengan baik melalui sistem aplikasi yang telah dibuat.

Manfaat dari penelitian pengembangan ini adalah: 1) sebagai bahan masukan untuk merumuskan suatu kebijakan atau strategi dalam menghadapi perkembangan penggunaan teknologi informasi sebagai sarana pengembangan pendidikan dalam bidang manajemen sumber daya manusia. 2) sebagai bahan masukan untuk membuat kebijakan dalam menentukan permasalahan di 
bidang manajemen sumber daya manusia. 3) sebagai bahan masukan bagi penentu kebijakan, khususnya yayasan pendidikan anak saleh dalam kaitannya dengan perencanaan strategis untuk pengembangan dan penyempurnaan teknologi informasi di bidang kepegawaian. 4) dengan adanya aplikasi kepegawaian, pendidik dan tenaga kependidikan dapat menambah referensi dalam pengembangan ilmu pengetahuan sebagai bentuk pemanfaatan teknologi informasi dalam bidang manajemen sumber daya manusia. 5) mempermudah pendidik dan tenaga kependidikan dalam mengakses tingkat kehadiran sehari-hari, sehingga dapat meningkatkan kualitas bekerja.

\section{DAFTAR RUJUKAN}

Fajrin, T. 2012. Analisis Sistem Presensi Dengan Sidik Jari Siswa SMK Negeri 2 Karangayar. Indonesian Jurnal On Computer Science Speed - FTI UNSA Vol 9 No 3 - Desember 2012.
Hasibuan, M.S.P. 2007. Manajemen Sumber Daya Manusia. Jakarta: Bumi Aksara.

Huda. 2010. Kajian Filosofis Otonomi Daerah Bidang Pendidikan. Malang: Fakultas Ilmu Pendidikan Universitas Negeri Malang.

Surjono, H.D. 2009. Pengenalan Dan Pengembangan E-Journal. (Online). (http://herman surjono/hermansurjono.uny.ac.id). Di akses 29 Januari 2014.

Suryana, H. 2007. Pengembangan E-Journal Universitas Sumatera Utara Menggunakan Open Journal System (OJS). (online). (http://digilab.unsu.ac.id). Diakses 2 Januari 2014. 